\title{
Changing profile of GAD and IA-2 antibody positivity in Indian children with recently diagnosed type 1 diabetes mellitus
}

\section{ABSTRACT}

Introduction. Published literature on type 1 diabetes (T1DM) patients from India suggests that a substantial number of them are negative to GAD 65 and IA-2 antibodies. Antibody positivity rates have been linked to dietary and socio-economic factors and more recently, to changes in the enterobiome. Our anecdotal evidence indicated that antibody positivity rates among newly diagnosed T1DM children were rising. In this presentation we have formally collated our data on these antibodies, a first, we believe, in the Indian pediatric population.

Material and methods. T1DM was diagnosed by standard clinical criteria advocated by American Diabetes Association including in all patients, the presence of diabetic ketoacidosis (DKA). We used plasma blood glucose rather than $\mathrm{A} 1 \mathrm{C}$ to diagnose the acute onset of type 1 diabetes in individuals with symptoms of hyperglycemia. All patients with this diagnosis had GAD (glutamic acid decarboxylase) and IA-2 (insulinoma antigen 2) antibodies measured as a routine procedure from 2007. Data on patients between the ages of 1 and 16 years as on $31^{\text {st }}$ August 2016 were collected for this study. The antibodies were measured by standard RIA kits from the same manufacturer and performed in the endocrinology laboratory of one of the institutions. Results. We included 694 T1DM cases from 2007 till

Address for correspondence:

Debmalya Sanyal

36 Block H New Alipore Kolkata

West Bengal, India, Zip code: 700053

Mobile: 0091-9830118388

e-mail: drdebmalyasanyal@gmail.com,

dr_debmalya@hotmail.com

Clinical Diabetology 2019, 8, 2, 116-120

DOI: $10.5603 /$ DK.2019.0005

Received: 06.12.2018 Accepted: 19.02.2019
2016, out of which 296 were antibody positive. A total of 172 were GAD antibody positive, 62 were IA-2 antibody positive and 90 exhibited dual antibody positivity (GAD positive + IA-2 positive). The chi-square test for trend analysis showed a significant rising trend for IA-2 antibody alone positive ( $p<0.001$, chi-square for trend $=17.437$, df $=1$ ) and either antibody positive percentages $(p<0.001$, chi-square for trend $=22.71$, df $=1$ ), but not in the GAD antibody positivity ( $p=$ 0.059 , chi-square for trend $=3.567, \mathrm{df}=1$ ) and in dual antibody positive percentages ( $p=0.486$, chi-square for trend $=0.485, d f=1$ ) over a period of 9 years i.e. from 2007 to 2016.

Conclusion. Antibody positivity rates in recently diagnosed T1DM children have changed fairly rapidly over the last nine years. This surge in autoimmunity may also be a significant contributing factor towards the recent increased incidence of T1DM in India. (Clin Diabetol 2019; 8, 2: 116-120)

Key words: type 1 diabetes mellitus, autoantibody, children, India

\section{Introduction}

Type 1 diabetes mellitus (T1DM) is a disease caused by an autoimmune destruction of $\beta$-cells, and is clinically manifest when almost $90 \%$ of pancreatic islet $\beta$-cells are destroyed $[1,2]$. It is a T-cell - mediated disease caused predominantly by CD4 positive cells. Islet cell antibodies (ICA), glutamic acid-decarboxylase (GAD65) antibodies, and insulin auto antibodies (IAA) are positive at diagnosis in over $85 \%$ of Western T1DM patients [3-7]. The incidence of T1DM is growing at a rate of $3-5 \%$ every year $[8,9]$. Of the world wide estimate of 490,000 children with T1DM, $24 \%$ are in the European 
region and $23 \%$ in the South East Asian region [10]. There are an estimated prevalence of 97,700 children with T1DM in India with an annual incidence of 3 new patients with T1DM per 100,000 children over a period of 13 years from 1995 to 2008 in the age group 0-16 years. Patients from India account for most of the pediatric prevalence of T1DM in South East Asia [11]. It has been hypothesized that environmental and microbial factors play a role in the rising incidence of T1DM [12]. Alterations in the composition of the enterobiome have been experimentally linked with the development of T1DM. In Non-Obese Diabetic (NOD) mice, a standard model of T1DM, the males have a lower incidence of T1DM than females. If the enterobiome of the male is altered to the female pattern, the incidence of T1DM rises to the female rate [13-16].

Historically, more than $40 \%$ of T1DM patients in India were antibody negative [17]. There are no significant studies from India tracing the change in auto-antibody positivity in recently diagnosed T1DM. We wanted to determine whether the antibody positivity of newly diagnosed T1DM children patients have changed since 2007 , i.e. since the time we have been performing antibody measurements.

\section{Materials and methods}

The current study was a retrospective study, performed in two secondary referral endocrine clinics. The protocol was presented to the Ethics Committees of the two centers who felt that given the retrospective chart review nature of the study, informed consent is not neccesary We used plasma blood glucose rather than A1C to diagnose the acute onset of type 1 diabetes in individuals with symptoms of hyperglycemia. Patients with DKA and typical clinical features of T1DM as per the American Diabetes Association (ADA) position statement of 2017 and aged 1-16 years were included in the study [18]. In this retrospective chart review, we have only included patients with a confirmed diagnosis of type 1 diabetes, diagnosed by standard clinical criteria advocated by American Diabetes Association. All our patients had confirmed diagnosis of diabetic ketoacidosis (DKA) along with ketonuria. This finding strengthened the clinical diagnosis of T1DM in our patients and ensured that young type 2 diabetes patients were excluded.

Patients with pancreatitis, any feature suggestive of type 2 diabetes (T2DM), and diabetes from secondary causes were excluded from the study. Neonatal diabetes was excluded by age as the lower age limit for inclusion in the study is one year. Patient records meeting the eligibility criteria were evaluated from January 2007 to $31^{\text {st }}$ August 2016. Blood samples were collected for estimation of glucose, C-peptide, GAD and IA-2 autoantibody in all patients. Venous blood sampling was done once the acute metabolic crisis was over and before oral feeding was allowed, in one center and after discharge in the other center. Lipemic or grossly haemolysed samples were discarded and the test repeated. The kits used came from the same manufacturer all through and the tests were done in one center. Antibodies to glutamic acid decarboxylase (GAD) and insulinoma antigen-2 were measured in all newly diagnosed T1DM patients' ( $n=692)$. Serum C-peptide values were required to be below the reference range. The samples were centrifuged at 2000 r.p.m. (at room temperature) for $15 \mathrm{~min}$ to separate the plasma. Plasma was decomplemented by heating at $56^{\circ} \mathrm{C}$ for $30 \mathrm{~min}$ and stored in aliquots at $-20^{\circ} \mathrm{C}$ with $0.1 \%$ sodium azide as preservative. Serum GAD-Ab and IA-2 Ab titers were measured by I $^{125}$ RIA technique (DLD DIAGNOSTIKA, GmBH, GERMANY) and C-peptide was estimated by RIA (IMMUNOTECH, FRANCE) [19]. For GAD and IA-2 antibody a titer $\leq 1.0 \mathrm{U} / \mathrm{ml}$ was considered normal while for C-peptide a fasting value $\geq 1.1 \mathrm{ng} / \mathrm{ml}$ was considered normal. Precision within the assay series was evaluated by processing 10 serum replicates. For GAD-Ab, IA-2Ab and C-peptide the results were mean $5.1 \pm 0.96 \mathrm{U} / \mathrm{ml}$ (\%CV 3.9), mean $3.6 \pm 0.85 \mathrm{U} / \mathrm{ml}(\% C V$ 2.7) and mean $1.05 \pm 0.14 \mathrm{ng} / \mathrm{ml}(\% \mathrm{CV} 0.8)$ respectively. The assay sensitivities for GAD-Ab, IA-2Ab and C-peptide were $0.21 \mathrm{U} / \mathrm{ml}, 0.19 \mathrm{U} / \mathrm{ml}$ and $0.036 \mathrm{ng} / \mathrm{ml}$ respectively, as obtained from kit literature. It may be noted that the ADA does not advise measurement of C-peptide, thyroid function tests or screening for celiac disease during the initial metabolic crisis $[20,21]$. This is because $C$-peptide values can be excessively depressed at this time, while thyroid function tests can be vitiated due to sick euthyroid syndrome and celiac screening affected by the lack of usual oral intake of gluten.

\section{Statistical methods}

Descriptive statistical analysis were carried out with SAS (Statistical Analysis System) version 9.2 for windows, SAS Institute Inc. Cary, NC, USA and Statistical Package for Social Sciences (SPSS Complex Samples) Version 21.0 for windows, SPSS, Inc., Chicago, IL, USA, with Microsoft Word and Excel being used to generate graphs and tables. Results on categorical measurements are presented in Number (\%). Significance is assessed at a level of $5 \%$.

\section{Results}

Auto-antibody positivity to $\beta$-cell antigens over a period of ten years i.e. from 2007 to 2016 is shown in Table 1. We included 694 T1DM cases from 2007 
Table 1. Pattern of number of autoantibodies to $\beta$-cell antigen in the study sample

\begin{tabular}{|c|c|c|c|c|c|c|}
\hline Year & $\begin{array}{c}\text { Total number } \\
\text { of cases } \\
N=694\end{array}$ & $\begin{array}{l}\text { GAD antibody } \\
\text { positive } \\
\mathrm{N}=172\end{array}$ & $\begin{array}{l}\text { IA-2 antibody } \\
\text { positive } \\
N=62\end{array}$ & $\begin{array}{l}\text { Both antibodies } \\
\qquad \begin{array}{c}\text { positive } \\
\mathrm{N}=90\end{array}\end{array}$ & $\begin{array}{c}\text { Both antibodies } \\
\begin{array}{c}\text { negative } \\
N=371\end{array}\end{array}$ & $\begin{array}{c}\text { Total positive } \\
\text { cases } \\
N=296\end{array}$ \\
\hline 2007 & 29 & $6(20.67)$ & $1(3.45)$ & $4(13.79)$ & $18(62.07)$ & $11(37.93)$ \\
\hline 2008 & 54 & $10(18.52)$ & 0 & 7 (12.96) & $37(68.52)$ & $17(31.48)$ \\
\hline 2009 & 70 & $12(17.14)$ & $4(5.7)$ & $7(10)$ & $47(67.14)$ & $23(32.86)$ \\
\hline 2010 & 91 & 17 (18.68) & $1(1.09)$ & $15(16.48)$ & $58(63.74)$ & $33(36.26)$ \\
\hline 2011 & 97 & 38 (39.18) & $2(20.62)$ & $11(11.34)$ & $46(47042)$ & $51(52.57)$ \\
\hline 2012 & 64 & $14(21.87)$ & 9 (14.06) & $6(9.38)$ & 35 (54.69) & $29(45.31)$ \\
\hline 2013-2014 & 203 & $53(26.11)$ & $31(15.27)$ & $19(9.36)$ & $101(49.75)$ & $102(50.25)$ \\
\hline 2015-2016 & 86 & $22(25.58)$ & $14(16.28)$ & $21(24.42)$ & $29(33.72)$ & $57(66.28)$ \\
\hline
\end{tabular}

GAD - glutamic acid decarboxylase; IA-2 - insulinoma antigen 2. Numbers in brackets denotes percentage

till 2016, out of which 296 were antibody positive. A total of 172 were GAD antibody positive, 62 were IA-2 antibody positive and 90 exhibited dual antibody positivity. The chi-square test for trend analysis showed a significant rising trend for IA-2 antibody alone positive $(p<0.001$, chi-square for trend $=17.437, \mathrm{df}=1)$ and either antibody positive percentages $(p<0.001$, chi-square for trend $=22.71$, df $=1$ ), but not in dual antibody positive percentages ( $p=0.486$, chi-square for trend $=0.485, \mathrm{df}=1$ ) and in GAD antibody positivity $(p=0.059$, chi-square for trend $=3.567, d f=1)$, though the $p$ value for GAD antibody positivity fell in the range of suggestive significance.

\section{Discussion}

For reasons unknown, low rates of antibody positivity are found in T1DM patients in Asia in comparison to their Western counterparts [4]. Prevalence of 26 to $61 \%$ of antibody positivity in T1DM patients has been reported from North India $[3,5]$. Tandon et al. have reported a $26 \%$ prevalence of GAD and/or IA-2Ab in T1DM patient with disease duration greater than 5 years in north India. They found a 14\% GAD positivity and $15 \%$ IA-2Ab positivity [4]. Some other studies [4] have reported higher rates of antibody positivity. Overall, variable antibody positivity rates have been reported from India, but were substantially lower than the $85-95 \%$ GAD positivity reported in Western populations [15-17].

Our study traced the autoantibody positivity of recently diagnosed T1DM patients over ten years in an East Indian pediatric population and found a secular trend of increased prevalence of antibody positivity (Table 1). Similar results were demonstrated by Ahmed et al. in 2008 where the authors found a prevalence of $47 \%$ of auto antibodies in their T1DM population. GAD65 antibody was positive in $41.2 \%$ and IA-2 in
20.6\%. A total of $14.7 \%$ TIDM subjects showed both GAD65 plus IA-2 autoantibody positivity [19].

There is a rising incidence of T1DM worldwide, and global estimates show significant increases of $4.0 \%$ in Asia, 3.2\% in Europe and 5.3\% in North America. The average annual increase in incidence of T1DM was $2.4 \%$ (95\% Cl 1.3-3.4\%) during 1990-1994, and a higher increase of $3.4 \%$ (95\% Cl 2.7-4.3\%) was recorded in the period 1995-1999. There is a suggestion in the Indian literature that the incidence of T1DM has been raising in the recent years [22]. Around 78,000 children under 15 years of age are estimated to develop T1DM annually worldwide. An estimated 18,000 children under the age of 15 were newly diagnosed with T1DM in 2011 in India [23]. In south India, the Karnataka Type 1 Diabetes Registry reported an incidence of 3.7/100,000 in boys' and 4.0/100,000 in girls, over 13 years of data collection [23]. Recently Kalra et al. reported a high prevalence (10.20/100,000 population) of T1DM in Karnal district in north India [24].

Wilkins had postulated an accelerator hypothesis where he linked weight gain with autoimmunity in T1DM in developed countries [25]. India being a fast developing country, has witnessed a rise in childhood obesity. Recently Jagadesan et al. had estimated $21.4 \%$ prevalence of childhood obesity among private school students in southern India [26]. Patterson and associates had further found a directly proportional relationship between national prosperity and childhood onset T1DM, which fits the data from India [27]. The hygiene hypothesis proposed by Gale and McKinney et al. which goes hand in hand with Patterson's hypothesis could also be one of the reasons for increases autoimmunity in our study sample $[28,29]$. This recent surge in autoimmunity of T1DM could be triggered by a change in the enterobiome of the population. A decade ago, in an Indian study of newly diagnosed T1DM, 
Balasubramanium and colleagues demonstrated mono GAD antibody positivity of $42 \%$ and IA-2 positivity of $33 \%$. Considering the absence of GAD and IA-2 Ab's in around $45 \%$ of the recently diagnosed Indian T1DM subjects, Bhatia postulated idiopathic (type 1B) patients to be substantially more frequent in the Indian population as compared to the Caucasian [30].

\section{Conclusion}

Our study traces the autoantibody positivity of recently diagnosed T1DM children over past ten years in an East Indian population and found a significant increase of autoantibody positivity over time. As this was an observational retrospective study, we could not assign any definite cause to this increase in autoimmunity. This surge in autoimmunity may be a significant contributing factor towards the recent reported increased incidence of TIDM in India.

\section{Limitations}

We have not included ZnT8 in our analysis since it is recently added in the panel of auto-antibodies for screening of T1DM from 2012 onwards. Since, we have included T1DM patients diagnosed from the year 2007; we wanted to maintain uniformity of the tested antibody in the study. Hence the antibody ZnT8 was not tested.

\section{Conflict of interest}

The authors declare no conflicts of interest in relation to this article.

\section{Author contributions}

D.S and S.C. was involved in designing the study, data collection, data entry and writing of manuscript. S.M. and S.B. were involved in data collection and biochemical and pathological investigations. All authors reviewed the manuscript.

\section{REFERENCES}

1. Steck AK, Johnson K, Barriga KJ, et al. Age of islet autoantibody appearance and mean levels of insulin, but not GAD or IA-2 autoantibodies, predict age of diagnosis of type 1 diabetes: diabetes autoimmunity study in the young. Diabetes Care. 2011; 34(6): 1397-1399, doi: 10.2337/dc10-2088, indexed in Pubmed: 21562325.

2. Das AK, Shtauvere-Brameus A, Sanjeevi CB. GAD65 and ICA512 antibodies in undernourished and normally nourished south Indian patients with diabetes. Ann N Y Acad Sci. 2002; 958: 247-250, indexed in Pubmed: 12021116.

3. Singh AK, Bhatia $E$, Dabadghao $P$, et al. Role of islet autoimmunity in the aetiology of different clinical subtypes of diabetes mellitus in young north Indians. Diabet Med. 2000; 17(4): 275-280, indexed in Pubmed: 10821293.

4. Tandon N, Shtauvere-Brameus A, Hagopian WA, et al. Prevalence of ICA-12 and other autoantibodies in north Indian patients with early-onset diabetes. Ann N Y Acad Sci. 2002; 958: 214-217, indexed in Pubmed: 12021109.

5. Harrison LC, Honeyman MC, DeAizpurua HJ, et al. Inverse relation between humoral and cellular immunity to glutamic acid decarboxylase in subjects at risk of insulin-dependent diabetes. Lancet. 1993; 341(8857): 1365-1369, indexed in Pubmed: 8098789.

6. Kaufman DL, Clare-Salzler M, Tian J, et al. Spontaneous loss of T-cell tolerance to glutamic acid decarboxylase in murine insulin-dependent diabetes. Nature. 1993; 366(6450): 69-72, doi: 10.1038/366069a0, indexed in Pubmed: 7694152.

7. Orban T, Sosenko JM, Cuthbertson D, et al. Diabetes Prevention Trial-Type 1 Study Group. Pancreatic islet autoantibodies as predictors of type 1 diabetes in the Diabetes Prevention Trial Type 1. Diabetes Care. 2009; 32(12): 2269-2274, doi: 10.2337/ dc09-0934, indexed in Pubmed: 19741189.

8. DIAMOND Project Group. Incidence and trends of childhood type 1 diabetes worldwide 1990-1999. Diabet Med. 2006; 23(8): 857-866, doi: 10.1111/j.1464-5491.2006.01925.x, indexed in Pubmed: 16911623.

9. TEDDY Study Group. The Environmental Determinants of Diabetes in the Young (TEDDY) study: study design. Pediatr Diabetes. 2007; 8(5): 286-298, doi: 10.1111/j.1399-5448.2007.00269.x, indexed in Pubmed: 17850472.

10. Aguiree F, Brown A, Cho NH, et al. IDF Diabetes Atlas. 6th ed. Brussels, Belgium: International Diabetes Federation, 2013.

11. Kumar KM, Azad K, Zabeen B, Kalra S. Type 1 diabetes in children: Fighting for a place under the sun. Indian J Endocrinol Metab. 2012; 16 Suppl 1: 1-3.

12. King ML, Bidwell D, Voller A, et al. Role of Coxsackie B viruses in insulin-dependent diabetes mellitus. Lancet. 1983; 2(8355): 915-916, indexed in Pubmed: 6137728.

13. King ML, Shaikh A, Bidwell D, et al. Coxsackie-B-virus-specific IgM responses in children with insulin-dependent (juvenile-onset; type I) diabetes mellitus. Lancet. 1983; 1(8339): 1397-1399, indexed in Pubmed: 6134178.

14. Szopa TM, Titchener PA, Portwood ND, et al. Diabetes mellitus due to viruses - some recent developments. Diabetologia. 1993; 36(8): 687-695, indexed in Pubmed: 8405735.

15. Banatvala JE, Bryant J, Schernthaner G, et al. Coxsackie B, mumps, rubella, and cytomegalovirus specific IgM responses in patients with juvenile-onset insulin-dependent diabetes mellitus in Britain, Austria, and Australia. Lancet. 1985; 1(8443): 1409-1412, indexed in Pubmed: 2861361.

16. Wenzlau JM, Juhl K, Yu L, et al. The cation efflux transporter ZnT8 (SIc30A8) is a major autoantigen in human type 1 diabetes. Proc Natl Acad Sci U S A. 2007; 104(43): 17040-17045, doi: 10.1073/ pnas.0705894104, indexed in Pubmed: 17942684.

17. Bhatia E. Type 1 diabetes mellitus in India. Curr Diab Rep. 2012; 12(3): 224-226, doi: 10.1007/s11892-012-0267-6, indexed in Pubmed: 22453674.

18. American Diabetes Association Classification and diagnosis of diabetes. Sec. 2. In Standards of Medical Care in Diabetes-2017. Diabetes Care. 2017; 40(Suppl. 1): S11-S24.

19. Ahmad J, Siddiqui M, Ahmed F, et al. Prevalence of autoantibodies and risk estimation of development of youth onset type 1 diabetes in northern India. Diabetes \& Metabolic Syndrome: Clinical Research \& Reviews. 2008; 2(1): 59-64, doi: 10.1016/j. dsx.2007.12.002.

20. American Diabetes Association. Standards of medical care in diabetes - 2013. Diabet Care. 2013; 36: S11-S66.

21. Sud S, Marcon M, Assor E, et al. Celiac disease and pediatric type 1 diabetes: diagnostic and treatment dilemmas. Int J Pediatr Endocrinol. 2010; 2010: 161285, doi: 10.1155/2010/161285, indexed in Pubmed: 20652072.

22. Kumar KM. Incidence trends for childhood type 1 diabetes in India. Indian J Endocrinol Metab. 2015; 19(Suppl 1): S34-S35, doi: 10.4103/2230-8210.155378, indexed in Pubmed: 25941646.

23. Kumar P, Krishna P, Reddy SC, et al. Incidence of type 1 diabetes mellitus and associated complications among children and young 
adults: results from Karnataka Diabetes Registry 1995-2008. J Indian Med Assoc. 2008; 106(11): 708-711, indexed in Pubmed: 19368094.

24. Kalra S, Kalra B, Sharma A. Prevalence of type 1 diabetes mellitus in Karnal district, Haryana state, India. Diabetol Metab Syndr. 2010; 2: 14, doi: 10.1186/1758-5996-2-14, indexed in Pubmed: 20214794.

25. Wilkin TJ. The accelerator hypothesis: weight gain as the missing link between type i and type II diabetes. Diabetologia. 2001; 44(7): 914-922, doi: 10.1007/s001250100548, indexed in Pubmed: 11508279.

26. Jagadesan S, Harish R, Miranda P, et al. Prevalence of overweight and obesity among school children and adolescents in Chennai. Indian Pediatr. 2014; 51(7): 544-549, indexed in Pubmed: 25031132.
27. Patterson CC, Dahlquist G, Soltész G, et al. Is childhood-onset Type I diabetes a wealth-related disease? An ecological analysis of European incidence rates. Diabetologia. 2001; 44(S3): B9-B16, doi: $10.1007 / \mathrm{pl} 00002961$

28. Gale EAM. A missing link in the hygiene hypothesis? Diabetologia. 2002; 45(4): 588-594, doi: 10.1007/s00125-002-0801-1, indexed in Pubmed: 12032638.

29. McKinney PA, Okasha M, Parslow RC, et al. Early social mixing and childhood Type 1 diabetes mellitus: a case-control study in Yorkshire, UK. Diabet Med. 2000; 17(3): 236-242, indexed in Pubmed: 10784230.

30. Balasubramanian K, Dabadghao P, Bhatia V, et al. High frequency of type 1B (idiopathic) diabetes in North Indian children with recent-onset diabetes. Diabetes Care. 2003; 26(9): 2697, indexed in Pubmed: 12941746. 